\title{
Improving the Reproductive Efficiency of the Goat: Vaginal Cytology and Vulvar Biometry as Predictors of Synchronized Estrus/Breeding Time in West African Dwarf Goat
}

\author{
Mejora de la Eficiencia Reproductiva de la Cabra: Citología Vaginal y Biometría Vulvar como \\ Predictores de la Sincronización del Periodo Estro/Crianza de Cabras Enanas del Oeste Africano
}

*Olufisayo Oluwadamilare Leigh; **Ayobami Kabir Raheem \& ${ }^{* * * *}$ Joseph Adebisi Oluwadamilare Olugbuyiro

LEIGH, O. O.; RAHEEM, A. K. \& OLUWADAMILARE, O. J. A. Improving the reproductive efficiency of the goat: Vaginal cytology and vulvar biometry as predictors of synchronized estrus/breeding time in West African dwarf goat. Int. J. Morphol., 28(3):923928, 2010.

SUMMARY: The characteristics of exfoliated vaginal cells and vulvar biometry following estrus synchronization via two injections of $5 \mathrm{mg}$ Lutalyse ${ }^{\circledR}$ administered 7 days apart were investigated with the aim of their possible use to predict estrus in six adult WAD does. Four adult WAD bucks recently passed as satisfactory potential breeders were also involved in the study. The animals were maintained on $12 \%$ crude protein concentrate, greens and fresh water ad libitum. All measurements in the does were taken at an interval of 24 hours for six days beginning with the day of $2^{\text {nd }}$ Lutalyse ${ }^{\circledR}$ injection. The does were introduced to the bucks 48 hours after the 2 nd dose of Lutalyse ${ }^{\circledR}$ and separated from them after the $6^{\text {th }}$ day. The $72-96$ and $96-120$ hours vaginal smears of 5 does (i.e. 83.3\%) were characteristic during the study. They were positive for sperm cells and showed sharp increase in the degree of clumping of exfoliated cells. During these periods also, the differences in the percentage of superficial cells (i.e. $77.4 \pm 1.05$ and $56.4 \pm 0.77$ ) over other epithelial cells (12.2 \pm 0.38 and $1.30 \pm 0.82)$ respectively were significant $(\mathrm{P}<0.05)$. The percentage leucocytes also varied during the study but increased sharply during 96 -120hours. The result on vulvar biometry between 0-72 hours and the period during which mating occurred (i.e. $72-120$ hours) was not significant $(\mathrm{P}>0.05)$. All does with vaginal smear positive for sperm cells were confirmed pregnant at day 60 following mating by ultrasonography. The results of this study show that two injections of $5 \mathrm{mg}$ Lutalyse ${ }^{\circledR} 7$ days apart will produce fertile estrus in the WAD doe. In conclusion, a careful evaluation of 24 hourly exfoliated vaginal cells will enhance synchronized estrus detection in WAD goat and improve their reproductive efficiency.

KEY WORDS: Vaginal cytology; Vulva biometry; Synchronization; Lutalyse $®$; Predict; Estrus; Doe.

\section{INTRODUCTION}

Under scientific rearing methods, the West African dwarf (WAD) goat has the potential to contribute immensely to the economy of the small holder arable farmer in Nigeria. Since the 1990's, Nigeria was estimated to house about 13\% (i.e. 22million) of the entire goat population of the African continent (FAO, 1991) where goat meat accounted for more than $20 \%$ of the total meat consumed by man (Brinkmann \& Adu, 1977). Despite the fact that about $85 \%$ of the small holder farmers in Nigeria kept goats (Bayer, 1986), the animal protein intake in Nigeria as in other third world countries is still below the minimum recommendation of the WHO
(Aromolaran \& Bamigbose, 1999). This is majorly due to low productivity of our indigenous species of livestock engendered by our reliance on traditional breeding methods which do not allow for accurate estrus detection and scientific reproductive management, thus leading to enormous reproductive wastages. Estrus synchronization and vaginal cytology are techniques capable of improving the reproductive potential of livestock. Estrus synchronization in livestock has greater influence on the luteal phase because of the longer duration of this phase and its greater responsiveness to manipulation (Ball \& Peters, 2004). PGF2a

\footnotetext{
* Department of Veterinary Surgery and Reproduction, Faculty of Veterinary Medicine, University of Ibadan.

** Department of Veterinary Surgery and Theriogenology, Michael Opara University of Agriculture, Umudike, Nigeria.

*** Department of Chemistry, Covenant University, Ota, Nigeria.
} 
preparations have been reported to be effective during the luteal phase in a number of studies in which the twoinjection method with 5-15mg, 11days apart of Lutalyse ${ }^{\circledR}$ was used (Akusu \& Egbunike, 1984; Ishwar \& Pandey, 1992; Ahmed et al., 1998). The application of vaginal cytology as a useful tool for estrus detection in modern breeding stations has been described for some species and breeds of animals (Pretorius, 1977; Rodgers, 1993; PerezMartinez et al., 1999; Oke \& Oke, 1999; Ola et al., 2006). In the recent study by Ola et al., the pattern of vaginal cell exfoliation was studied during natural cycles in the WAD goat. The objective of the present study was to investigate the pattern of vaginal cellular exfoliates which are depictive of estrus in female WAD goats (does) synchronized with Lutalyse ${ }^{\circledR}$ with the aim to recommend its practice for use in goat breeding stations. The administration of Lutalyse $\AA$ as two injections, 7days apart instead of the usual 10-14 days interval was also investigated if it would result in estrus in the experimental animals. Changes in vulvar dimensions were also investigated for the possibility of usage as a predictor of estrus. These will assist in accurate detection of estrus and enhance fertility in modern breeding stations for WAD goat does.

\section{MATERIAL AND METHOD}

Experimental Animals and management: Ten goats (caprine species) consisting of four West African dwarf (WAD) bucks and six adult WAD does which had been kept on the University farm for more than four months were involved in the study. The does were between 10 and 30 months old, weighing $11-20 \mathrm{~kg}$. They were housed in the Small ruminant section of the Department of Veterinary Surgery and Reproduction, University of Ibadan, Nigeria. The does were housed together in a separate pen from that of the bucks. They were fed with Elephant grass in the mornings and concentrate (12\% CP) in the evenings. Feeds and freshwater were provided ad libitum. Fresh water was also provided ad libitum throughout the study. The does were introduced to the breeding pen containing the bucks about 48 hours after the second injection of Lutalyse $®$. They were also separated from the bucks after the sixth day following second administration of Lutalyse ${ }^{\circledR}$. The study was conducted between April and September, 2009.

Oestrus synchronization: Two injections of PGF2a (Lutalyse®; Pharmacia \& Upjohn) was administered to the six does 7days apart. For the two injections per animal, a total of $10 \mathrm{mg}$ Lutalyse ${ }^{\circledR}$ (i.e. $5 \mathrm{mg}$ per injection) was administered using the intramuscular route.
Vaginal cytology: Vaginal smears were taken daily from the six WAD does using small ruminant vaginal swabs that were earlier moistened in normal saline. The vulva and perineum were rinsed with saline and dried with a clean towel. Each doe was well restrained in standing position by an assistant and the swab was gently inserted with the right hand while the left thumb and fore-finger (gloved) were used to expose the vulva lips. At the anterior vagina, the swab was gently rolled against the vaginal mucosa and carefully withdrawn. The swab was immediately smeared on a glass slide and stained with Giemsa. This process was performed on a 24 hourly basis between 0 (i.e. the hour of $2^{\text {nd }}$ Lutalyse ${ }^{\circledR}$ injection) and 144 hours. The cells found in the vaginal smear were summarized as percentage epithelial cells and leucocytes except for the period during which sperm cells were observed in the smear and the exfoliated vaginal cells were categorized as percentage superficial and other (i.e. parabasal, intermediate and leucocyte) cells. Such summary of cell types was considered for possible use as a predictor of estrus. 25 cells were counted from 4 fields of each slide and the percentage of each cell type was recorded.

Vulvar biometry: The diameters of the vulva i.e. vertical (distance between superior and inferior commissure) and horizontal (at the broadest horizontal curvature) were measured using Vernier calipers for the six does for six days starting from the day of second injection of Lutalyse®.

Pregnancy diagnosis: Methods of ultrasonography regarding the estimation of crown rump length (CRL) for estimation of fetal age (Abdelghafar et al., 2007) were used to examine the does for pregnancy at day 60 following the observation of sperm cells in the vaginal smears.

Data analysis: Data collected during the study were subjected to standard statistical analysis using the Student's -t- test (Elston \& Johnson, 2008).

\section{RESULTS}

The results obtained during the study are presented below:

Oestrus synchronization: Five( $83.3 \%)$ out of the six does treated with two injections of Lutalyse ${ }^{\circledR}$ (i.e. $5 \mathrm{mg}, 7$ days apart) were discovered to have shown standing heat which was depicted by the presence of numerous sperm cells in their vaginal smears. Based on the period sperm cells were found in the vaginal smear, the does were observed to have been mated between 72 and 120hours after the second injection of Lutalyse ${ }^{\circledR}$ as shown in Table 1. 
Table I. Percentages of epithelial cells and leucocytes as well as the degree of clumping and presence of sperm cells during the study.

\begin{tabular}{lcccc}
\hline $\begin{array}{l}\text { Hours } \\
\text { Lutalyse }{ }^{\text {after }} \text { injection }\end{array}$ & $\begin{array}{c}\mathbf{2}^{\text {nd }} \\
(\boldsymbol{\%})\end{array}$ & $\begin{array}{c}\text { Epithelial cells } \\
(\boldsymbol{\%})\end{array}$ & $\begin{array}{c}\text { Clumping } \\
\text { Presence of sperm } \\
\text { cells }\end{array}$ & $\begin{array}{c}\text { Pres } \\
24-48\end{array}$ \\
\hline $0-24$ & $16.0 \pm 0.03$ & $84.0 \pm 0.04$ & \pm & - \\
$48-72$ & $16.0 \pm 0.03$ & $84.0 \pm 0.16$ & + & - \\
$72-96$ & $70.1 \pm 0.35$ & $29.9 \pm 0.23$ & +++ & + \\
$96-120$ & $89.6 \pm 0.34$ & $10.4 \pm 0.56$ & +++ & +++ \\
$120-144$ & $57.7 \pm 0.68$ & $42.3 \pm 0.07$ & ++ & ++ \\
\hline
\end{tabular}

*differences between epithelial cells and leucocytes during 0-144hours were significant $(\mathrm{P}<0.05)$.

Vaginal cytology: The slides on vaginal cytology (Figs. 14) shows variation in percentages of epithelial cells, presence or absence and degree of clumping of epithelial cells as well as presence of sperm cells observed during the study. The

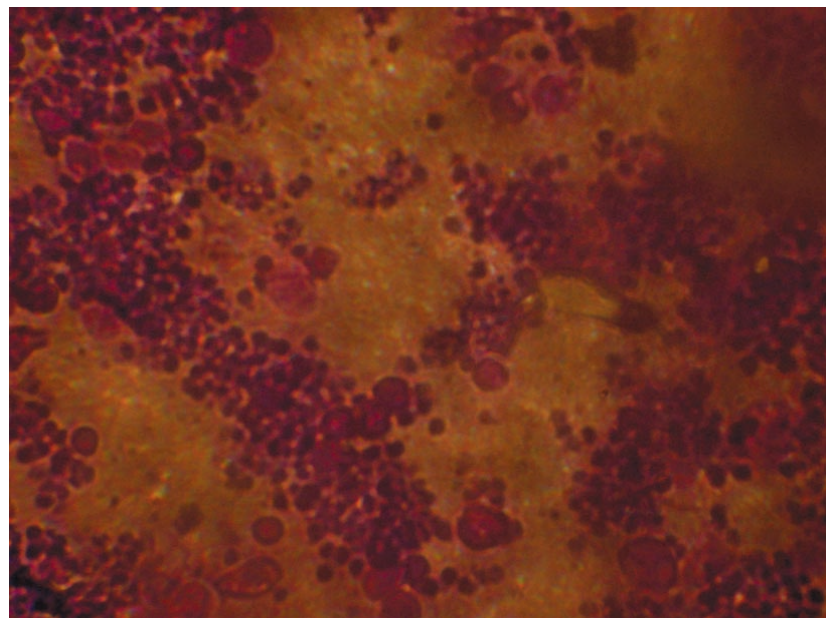

Fig. 1. Showing exfoliated cells ( \pm clumping) and numerous leucocytes about 24 hours after 2nd Lutalyse ${ }^{\circledR}$ injection. X400.

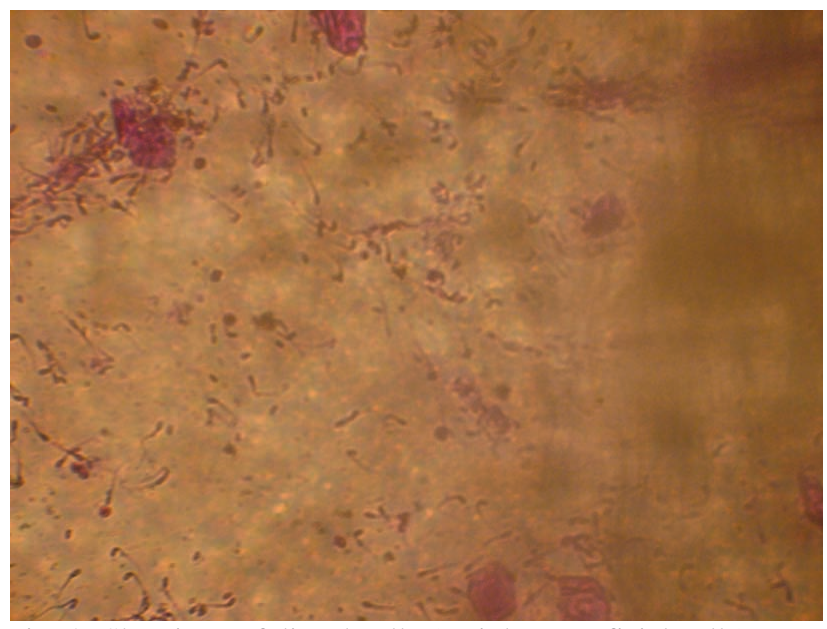

Fig. 3. Showing exfoliated cells (mainly superficial cells), very few leucocytes and numerous sperm cells about 96 hours after 2 nd Lutalyse ${ }^{\circ}$ injection. X400. observations found in the vaginal cytology during the study are presented in Tables I and II with the values summarized as Mean \pm S.D. Table I shows that the totality of cells encountered in the smears are constituted by epithelial cells

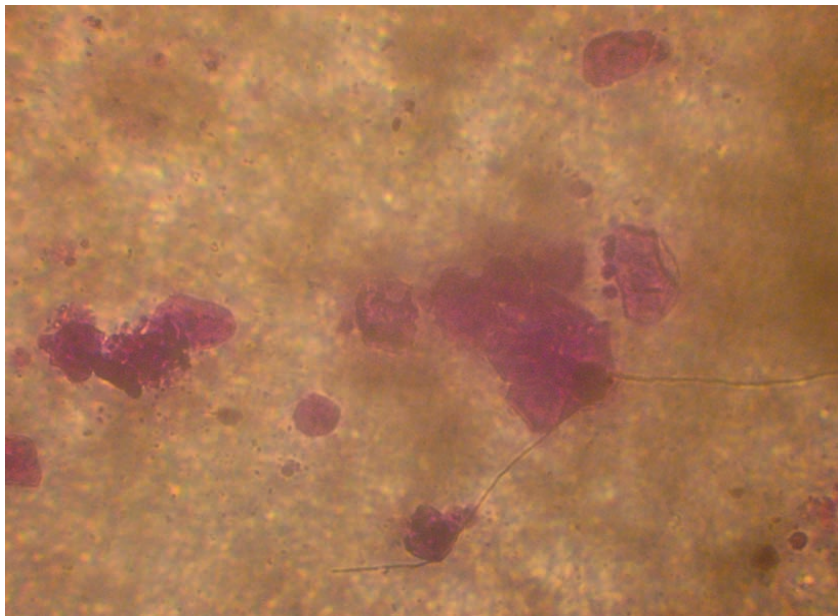

Fig. 2. Showing exfoliated cells (+++ clumping) and leucocytes about 72 hours after 2nd Lutalyse ${ }^{\circledR}$ injection. X400.

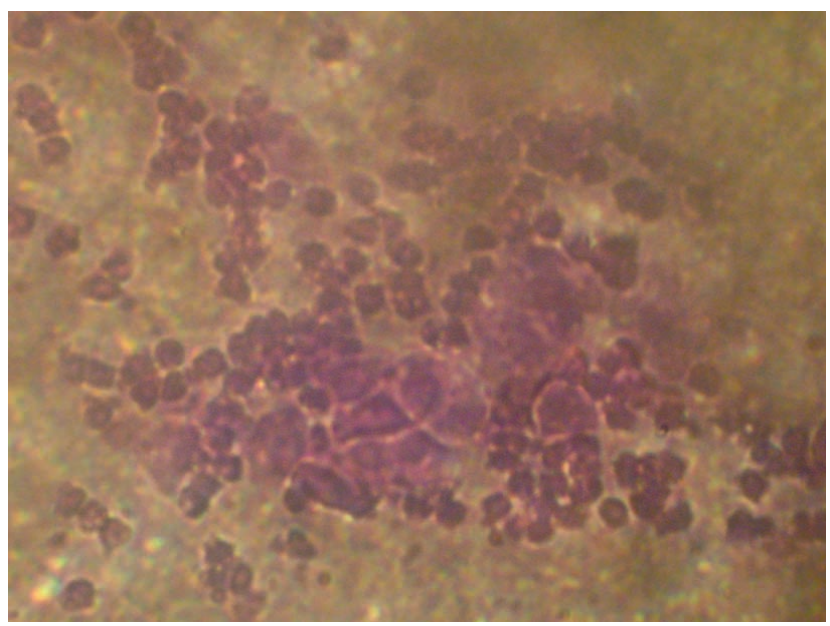

Fig. 4. Showing exfoliated cells and numerous leucocytes about 144 hours after 2nd Lutalyse ${ }^{\circledR}$ injection. X400. 
and leucocytes. The percentage epithelial cells rose sharply between the 0 -24hours of 2 nd Lutalyse ${ }^{\circledR}$ injection from $16.0 \pm 0.03 \%$ to $89.6 \pm 0.34 \%$ during the first 24 hours of standing estrus (i.e. $72-96$ hours) and decreases sharply also to $13.3 \pm 1.02 \%$ about 48 hours after the first observation of standing estrus. The leucocytes instead decreased from $84.0 \pm 0.04 \%$ (during 0 -24hours) to $10.4 \pm 0.56 \%$ during the first 24 hours of estrus, but picks up to $42.3 \pm 0.07 \%$ about 24 hours into mating. The differences between percentage epithelial cells and leucocytes for all the days were significant $(\mathrm{P}<0.05)$. Table 2 shows that the differences between superficial and other epithelial cells were also significant $(\mathrm{P}<0.05)$. During the first 24hours of acceptance of the male (as shown by presence of sperm cells), the percentage superficial cells was $77.4 \pm 1.05 \%$ which became $56.4 \pm 0.77 \%$ by the next 24 hours (i.e. 96-120hours). The other epithelial cells varied between $12.2 \pm 0.38 \%$ and $1.3 \pm 0.82 \%$ respectively during 72 96 and 96-120hours.

Vulvar biometry: Table III shows the results on vulvar biometry during the study presented as Mean \pm S.D. The differences in the mean values of all measurements i.e. vertical and horizontal vulva dimensions between the $0-72$ hours of non appearance of sperm cells in the smear and the 72120hours during which mating occurred were not significant $(\mathrm{P}>0.05)$.

Pregnancy: All five does whose vaginal smear were positive for sperm cells were confirmed pregnant at day 60 post mating using the methods of ultrasonography.

Table II. Percentage occurrence(s) of superficial and other cells (parabasal, intermediate) during induced estrus in the study.

\begin{tabular}{lccc}
\hline Period in estrus (hours) & Superficial cells $(\%)$ & Other cells $(\%)$ & p-value \\
\hline $72-96$ & $77.4 \pm 1.05$ & $12.2 \pm 0.38$ & $\mathrm{p}<0.05$ \\
$96-120$ & $56.4 \pm 0.77$ & $1.30 \pm 0.82$ & $\mathrm{p}<0.05$ \\
\hline
\end{tabular}

Table III. Mean values for vulvar biometry between 0-72 and 72-120 hours following 2nd injection of Lutalyse ${ }^{\circledR}$ in the study.

\begin{tabular}{lccc}
\hline Vulvar diameter & 0-72hours & 72-120hours & P-value \\
\hline Vertical $(\mathrm{cm})$ & $1.88 \pm 1.17$ & $1.85 \pm 1.23$ & $\mathrm{P}>0.05$ \\
Horizontal $(\mathrm{cm})$ & $1.52 \pm 1.12$ & $1.43 \pm 1.06$ & $\mathrm{P}>0.05$ \\
\hline
\end{tabular}

\section{DISCUSSION}

Lutalyse ${ }^{\circledR}$ is a derivative of PGF2a and one of the most potent luteolytic agent (Romano, 1998). Administration of exogenous PGF2a during the mid-luteal phase results in premature luteolysis with a resultant fall in peripheral progesterone concentration, which is followed by increased gonadotropin and oestradiol-17b secretion (Ball \& Peters). These processes eventually culminate in ovulation in intact female mammals (Noakes et al., 2001). In each of 5 WAD does treated using two intramuscular injections, 11 days apart with $5 \mathrm{mg}$ and $10 \mathrm{mg}$ Lutalyse ${ }^{\circledR}$, Akusu \& Egbunike, reported that estrus was achieved approximately 2 weeks earlier through reduction in average time to first estrus. The observation in the present study following the two injections of $5 \mathrm{mg}$ Lutalyse ${ }^{\circledR} 7$ days apart, in which $5(83.3 \%)$ of the 6 treated does were successfully mated showed that this regime of administration of PGF2a preparation to achieve oestrus synchronization in the WAD goat is successful and practicable. Only one doe which represented $17.7 \%$ was not mated as evidenced by the absence of sperm cells in the 24 hourly smears taken throughout the study. It is not clear why this doe was not mated even though the pattern of her vaginal exfoliates was similar to those of her pen-mates during the study and especially, around the time others were receptive to the bucks. This observation is of scientific interest in breeding management where it has been established that the male is the best detector of estrus in the female (Lauderdale \& Zimbelman, 1974). The present study does not contradict this fact but suggests that there is probably a minimum threshold of estrual signs which the female must exhibit either in natural or induced cycles for the male to detect/respond. There is possibility that the intensity of estrual signs also affect the concentration of pheromone produced by the females which consequently act as chemical attractant to the male. It is also possible that the failure to show overt estrual signs, at least to a level detectable by the buck, was related to inadequate level of chemical substance used to induce estrus (Greyling \& van der Nest, 2000). If this was the case with the single doe in the present study, it will imply that ovarian threshold to PGF2a differ with different animals. This is because of the other 5 pen-mates which responded to the luteolytic effect of $5 \mathrm{mg}$ Lutalyse ${ }^{\circledR}$ as was used in the study. These suggestions may explain some of the attributes of certain female animals classified as having silent estrus. Since four proven bucks that have just been passed 
as potential breeders were used against six does in the study, failure to observe sperm cells in the smear of the single doe could not have been due to male overuse or exhaustion. Similarly, since all 5 does whose vaginal smear was positive for sperm cells were confirmed pregnant, it suffices to suggest that the regime of oestrus synchronization adopted in this study is effective in inducing fertile estrus in the WAD goat. This regime is an improvement in terms of cost and time lag over the earlier published methods of administering two injections of PGF2a preparations 10-14 days apart to achieve oestrus synchronization (Akusu \& Egbunike; Greyling \& van Niekerk, 1986; Ishwar \& Pandey; Kusina et al., 2000). The results of the present study on artificially induced cyclical activity with regards to vaginal cytology in WAD does is similar to earlier reports (Perez-Martinez et al.; Ola et al.). Though superficial cells were found along with other epithelial cells and leucocytes throughout the study, the percentage superficial cells $(77.4 \pm 1.05 \%)$ was significantly $(\mathrm{P}<0.05)$ higher than for other epithelial cells $(12.2 \pm 0.38 \%)$ during the first 24 hours of mating. This period also corresponds to the time of most intense clumping of epithelial cells similar to the pattern described for canine (England, 1992). A careful study of Tables 1 and 2 also show that especially by the second 24hours of mating (i.e. 96-120 hours after 2nd Lutalyse ${ }^{\circledR}$ injection), $57.7 \%$ of all cells were epithelial cells and $56.4 \%$ of this, representing about $97.8 \%$ of all exfoliated vaginal cells was superficial at that period. This represents an increase of $11.4 \%$ over the $86.4 \%$ value of superficial cells for the preceding period (i.e. 72-96hours). These observations further suggest that such increase in percentage superficial cells may be used to predict estrus in the WAD doe. There was an increase in the percentage of leucocytes around estrus especially compared with the fall which had started some hours before sperm cells were found in the smears. The difference between the percentage leucocytes found between the first $(10.4 \pm 0.56)$ and second (42.3 \pm 0.07$)$ 24hours of mating was significant $(\mathrm{P}<0.05)$. This may be explained as a physiological response following mating to ward of possible infections that could be transmitted through coitus. These findings further lend credence to the effectiveness of adopting vaginal cytology for breeding management in the goat. This is because in cases where estrual signs are not overt enough to be detected by either the stockperson or the sire, the period for mating so as to achieve reasonable conception may be determined through vaginal cytology. Even the only doe whose vaginal smear was not positive for sperm cells was confirmed to have been in estrus through her pattern of vaginal exfoliates which were similar to those of her pen-mates, especially around estrus. The value of this study becomes even more appreciated in organized farms where they rely solely on oestrus synchronization and the technology of artificial insemination to produce calves, kids and lambs. The findings on pattern of vaginal exfoliates are similar to the observation of Ola et al. in their study on exfoliative vaginal cytology during physiological cycle in the WAD goat. The difference in vulvar biometry between 0-72 and 72-120 hours (i.e. period of mating) following 2 nd administration of Lutalyse $\left({ }^{\circledR}\right.$ was not significant $(\mathrm{P}>0.05)$. This is in agreement with earlier reports that changes in vulva tumefaction are not obvious enough to indicate heat in this species (Noakes et al.). The caprine is unlike the canine where considerable hypertrophy of the vulva can be used to detect physiological processes leading to estrus. The confirmation of pregnancy in $83.3 \%$ of the does used in the study implied that the presence of sperm cells found in the vaginal smears of the 5 does, between 72 and 120 hours, a period during which there was sharp increase in superficial cells and clumping of epithelial cells following 2nd Lutalyse $®$ injection, was responsible for the pregnancy. More so, the does were separated from the bucks after the 6th day following second administration of Lutalyse ${ }^{\circledR}$. Only one doe (17.7\%) was not pregnant and this was the doe whose vaginal smear though showed similar pattern of exfoliated cells with others, was negative for sperm cells. In conclusion, the results obtained in this study show that two injections, 7 days apart of exogenous PGF2a (Lutalyse ${ }^{\circledR}$ ) can be used to induce ovulatory estrus in the WAD doe; careful monitoring of exfoliated vaginal cells may be relied upon for detecting the time to mate so as to achieve conception in WAD does and also, changes in vulvar biometry is not a reliable indicator of estrus in the WAD goat doe.

LEIGH, O. O.; RAHEEM, A. K. \& OLUWADAMILARE, O. J. A. Mejora de la eficiencia reproductiva de la cabra: Citología vaginal y biometría vulvar como predictores de la sincronización del periodo estro/crianza de cabras enanas del Oeste Africano. Int. J. Morphol., 28(3):923-928, 2010.

RESUMEN: Fueron investigadas en seis cabras WAD hembras adultas, las características de las células vaginales exfoliadas y la biometría vulvar, tras una sincronización de estros a través de dos inyecciones de $5 \mathrm{mg}$ de Lutalyse ${ }^{\circledR}$, administrados cada 7 días, con el fin de hacer posible el uso y predecir el estro. También participaron en este estudio cuatro machos adultos WAD probados recientemente como potenciales reproductores. Los animales fueron alimentados con un concentrado de proteína cruda de $12 \%$, pastos y agua ad libitum. Las medidas en las cabras fueron tomadas con un intervalo de 24 horas, durante 6 días, a contar de la segunda inyección Lutalyse ${ }^{\circledR}$. Después de 48 horas de la $2^{\text {a }}$ dosis de Lutalyse ${ }^{\circledR}$ las cabras fueron cruzadas, y separadas de los machos después del $6^{\circ}$ día. Fue realizado el estudio en frotis vaginales de 72-96 horas y de 96-120 horas, en 5 hembras $(83,3 \%)$. Estos frotis fueron positivos para las células espermáticas y mostraron fuerte aumento en el grado de aglutinación de células de descamación. Durante estos períodos, las diferencias en el porcentaje de células superficiales $(77,4 \pm$ $1,05$ y $56,4 \pm 0,77)$ sobre las células epiteliales de otros $(12,2 \pm 0,38$ y $1,30 \pm 0,82)$ fueron significativas $(\mathrm{P}<0,05)$. También varió el porcentaje de leucocitos durante el estudio, pero aumentó considerablemente durante el periodo de 96-120 horas. El resultado de biometría vulvar entre 0-72 horas y del período durante el cual se 
produjo el apareamiento (72-120 horas) no fue significativa ( $\mathrm{P}>0,05)$. Todas las hembras con frotis vaginal positivo para células espermáticas, se les confirmó la preñez por ecografía, a los 60 días posterior al apareamiento. Los resultados de este estudio mostraron que dos inyecciones de $5 \mathrm{mg}$ Lutalyse ${ }^{\circledR}$ con 7 días de diferencia produce estro fértil en la cabra WAD. En conclusión, una evaluación cuidadosa de las células vaginales exfoliadas a las 24 horas, mejorará la detección del estro en cabras WAD y su eficiencia reproductiva.

PALABRAS CLAVE: Citología vaginal; Biometría vulvar; Sincronización; Lutalyse®; Predecir; Estro; Cabra.

\section{REFERENCES}

Abdelghafar, R. M.; Ahmed, B. H. \& Bakhiet, A.O. Ultrasonic measurements of crown-rump length and bi-parietal diameter to predict gestational age in Saanen goats. J. Anim. Vet. Adv., 6(3):454-7, 2007.

Ahmed, M. M. M.; Makawi, S. E. \& Jubara, A. S. Synchronization of oestrus in Nubian goats. Small Rum. Res., 30:113-20, 1998.

Akusu, M. O \& Egbunike, G. N. Fertility of the West African dwarf goat in its native environment following PGF2a induced oestrus. Veterinary Quarterly. 6:173-6, 1984.

Aromolaran, A.B \& Bamigbose, A.M. Comparative cost analysis of meat products and energy in Abeokuta, Nigeria. Trop. J. Anim. Sci. 2(1):185-93, 1999.

Ball, P. J. H \& Peters, A. R. Reproduction in cattle. $3^{\text {rd }}$ Ed. Oxford, Blackwell Publishing, 2004.

Bayer, W. Traditional small ruminant production in the subhumid zone of Nigeria. In: von Kaufmann R, Chater, S and Blench, R (eds.), Livestock systems research in Nigeria's subhumid zone. Proceedings of the Second ILCA/NAPRI Symposium held in Kaduna, Nigeria, 29 October-2 November, 1984. Ethiopia, ILCA, Addis Ababa, 1986. pp.141-66.

Brinkmann, W. L \& Adu, I. F. The problems of goat production in the savannah region of Nigeria. NAPRI Manuscript. Zaria, Nigeria, Ahmadu Bello University, 1977.

England, G. W. C. Vaginal cytology and cervico vaginal mucus arborisation in the breeding management of bitches. J. Small Anim. Pract. 33:577-82, 1992.

Elston, R. C \& Johnson, W. D. Basic Biostatistics for geneticists and epidemiologists. A Practical Approach. 1st Ed. UK., John Wiley and Sons Ltd., 2008.

FAO (Food and Agricultural Organization of the United Nations). Livestock and Livestock products. Quarterly Bulletin of Statistics. FAO, Rome, Italy. 4(3):39, 1991.
Greyling, J. P. C \& van der Nest, M. Synchronization of oestrus in goats: dose effect of progestagen. Small Rum. Res., 36:201-7, 2000.

Greyling, J. P. C \& van Niekerk, C. H. Synchronization of oestrus in the Boer goat doe: Dose effect of prostaglandin in the double injection regime. S. Afr. J. Anim. Sci., 16:146-50, 1986.

Ishwar, A. K \& Pandey, J. N. Oestrus synchronization and fertility in Black Bengal goats following administration of progesterone/ prostaglandin and gonadotropins. Res. Vet. Sci., 52:141-6, 1992.

Kusina, N. T.; Tarwirei, F.; Hamudikuwanda, H.; Agumba, G. \& Mukwena, J. A comparison of the effects of progesterone sponges and ear implants, PGF2a, and their combination of efficacy of estrus synchronization and fertility of Mashona goat does. Theriogenology, 53:1567-80, 2000.

Noakes, D. E.; Parkinson, T. J. \& England, G. C. W. Arthur"s Veterinary Reproduction and Obstetrics. New York, Saunders, 2001.

Lauderdale, J. W. \& Zimbelman, R. G. Techniques in female reproduction: Detection and synchronization of estrus. In: Reproduction in farm animals. E.S.E Hafez. $3^{\text {rd }}$ Ed. Philadelphia, Lea and Febiger, 1974. pp. 432-6.

Oke, O. A. \& Oke, B. O. Vaginal cytology changes during the oestrus cycle of the adult female African giant rat (Cricetomys gambianus). Tropical Vet., 17:167-80, 1999.

Ola, S. I.; Sanni, W. A. \& Egbunike, G. N. Exfoliative vaginal cytology during the oestrus cycle of West African dwarf goats. Reprod. Nutr. Dev., 46: 87-95, 2006.

Pretorius, P. S. Vaginal cytological changes in the cycling and anoestrus Angora goat doe. J. S. Afr. Vet. Assoc., 48:169-71, 1977.

Perez-Martinez, M.; Mendoza, M. .E \& Romano, M. C. Exfoliative vaginal cytology and plasma levels of estrone and estradiol-17b in young adult goats. Small Rum. Res., 33(2):153-8, 1999.

Rodgers, K. S. The canine estrus cycle: staging using vaginal cytology. Compend. Contin. Educ. Pract. Vet., 19: 1036-44, 1993.

Romano, J. E. Effect of two doses of cloprostenol in two schemes for estrous synchronization Nubian does. Small Rum. Res., 28:171-6, 1998.

Correspondence to:

Dr O. O. Leigh

Department of Veterinary Surgery and

Reproduction, University of Ibadan.

NIGERIA

Email: damilareolufisayo@yahoo.com

Received: 23-12-2009

Accepted: 16-03-2010 